\title{
Mycorrhizal Fungi
}

Erin L McDermott and Alison M Berry |

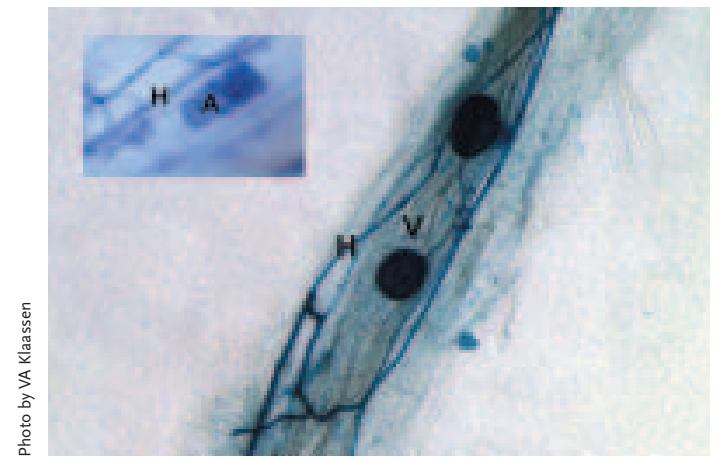

ABSTRACT

Different types of mycorrhizal associations occur on native plants. The 2 common types are arbuscular mycorrhizae and ectomycorrhizae. We briefly describe both types and how they can be identified by growers and planters of native plants.

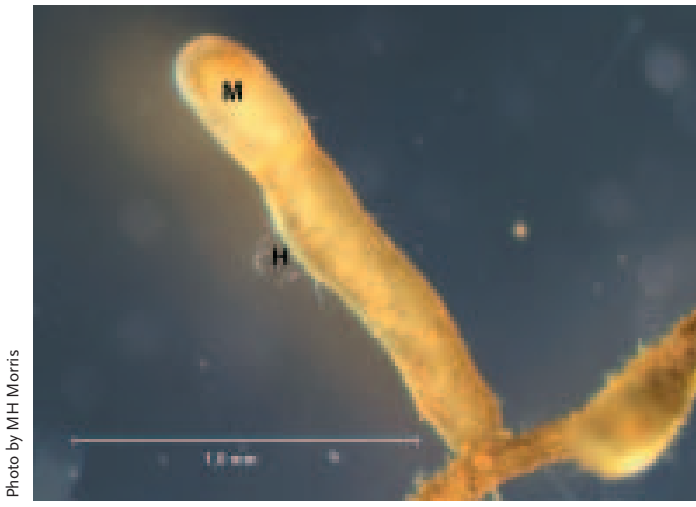

KEY WORDS arbuscular mycorrhizae, AMF, endomycorrhizae, vesicular-arbuscular mycorrhizae, VAM, ectomycorrhizae, ECM

NOM E N C LATURE Hickman (1993)

Figure 1. Top: stained grass root with hyphae $(\mathrm{H})$ and vesicles (V). Inset shows arbuscule (A) and hyphae. Bottom: An oak root with a mantle (M) and hyphae.

$\mathrm{M}$ ycorrhizal associations are symbiotic relationships between nearly all higher plants and soil fungi. The fungal partner increases uptake of nutrients to the plant while the plant provides photosynthate to the fungus. The 2 main types of mycorrhizal root associations are arbuscular mycorrhizae (AM, sometimes called endomycorrhizae or vesicular-arbuscular mycorrhizae [VAM]) and ectomycorrhizae (ECM).

Grasses, perennial herbs, and many trees and shrubs form associations with AM fungi (AMF; Table 1). Inside the fine roots of the host plant, the fungi characteristically form structures called arbuscules not visible to the naked eye but easily seen under a microscope (Figure 1). Most AM fungi belong to the fungal group Ascomycetales and reproduce by forming thick-walled spores that can remain viable in the soil for long periods of time.

Ectomycorrhizal fungi are associated primarily with woody species (Table 1 ). ECM roots are modified lateral roots, surrounded by a sheath of ECM fungi, called the mantle (Figure 1). ECM fungi are in the fungal group Basidiomycetales, and many produce the familiar mushrooms, some of which are prized edibles.

Although most plants form either AM or ECM, several plants (such as oaks, willows, and chamise) can be colonized by both (Table 1).

Most higher plants are mycorrhizal, but a small number of species, including many of our worst weeds, are non-hosts and do not form mycorrhizae (Table 1). These weed species may be better adapted to outcompete mycorrhizal plants in nu- trient-rich (eutrophic) soils where mycorrhizae are suppressed. Plants are mainly facultative mycotrophs, that is, they form mycorrhizal associations in low nutrient soils but do not require mycorrhizae for good growth if fertilized. This is why high rates of either nitrogen or phosphorus fertilizers applied in the nursery can suppress mycorrhizal development (Smith and Read 1997).

Root samples can be examined to confirm mycorrhizal colonization. ECM are visible to the naked eye or with a hand lens but AM requires lab processing. ECM are easier to spot: look at soilfree fine roots for the presence of the characteristic swollen root tips and mantle (Figure 1). For plants that form $\mathrm{AM}$, fine roots must be cleared, stained, and examined under a dissecting micro- 
Selected native plant taxa of western North America and the mycorrhizal associations they form. All names follow Hickman (1993).

$\begin{array}{lll}\text { Arbuscular Mycorrhizae } & & \\ \text { Calocedrus decurrens } & \text { Acer spp. } & \text { Asteraceae } \\ \text { Sequoia sempervirens } & \text { Ceanothus spp. } & \text { Fabaceae } \\ \text { Sequoiadendron giganteum } & \text { Cornus spp. } & \text { Lamiaceae } \\ \text { Thuja plicata } & \text { Epilobium spp. } & \text { Poaceae } \\ & \text { Fraxinus spp. } & \text { Ranunculaceae } \\ & \text { Juglans spp. } & \text { Rosaceae } \\ & \text { Lonicera spp. } & \text { Scrophulariaceae } \\ & \text { Prunus spp. } & \end{array}$

\section{Ectomycorrhizae}
Abies spp.
Lithocarpus spp.
Rhamnus spp.
Alnus spp.
Picea spp.
Pseudotsuga spp.
Betula spp.
Pinus spp.
Tsuga spp.
Corylus spp.
Arbuscular and Ectomycorrhizae
Adenostoma fasciculatum
Ribes spp.
Populus spp.
Salix spp.
Quercus spp.

\section{Non-Mycorrhizal \\ Brassicaceae \\ Chenopodiaceae \\ Cyperaceae}

scope, as in Figure 1 (Phillips and Hayman 1970). For more information on methods for working with mycorrhizae, the following websites may be useful: http://www.ffp.csiro.au/research/ mycorrhiza/and http://invam.caf.wvu.edu/.

The general consensus among experts is that mycorrhizal inoculation can be useful for restoration in degraded sites, but is not needed everywhere. It is not a cure-all for restoration projects. For nursery stock, mycorrhizae can make a good plant better but will not increase the quality of a poor plant. Many sites probably have sufficient native mycorrhizal fungi present. If inoculation is required, advance planning and preparation are necessary to produce needed even with mycorrhizal inoculation, weeds can invade, soil can erode, and plants can do poorly. The success of inoculation depends on a project-by-project assessment and should be used in combination with other restoration techniques.

\section{REFERENCES}

Hickman JC, editor. 1993. The Jepson manual: higher plants of California. Berkeley (CA): University of California Press. 1400 p.

Phillips JM, Hayman DS. 1970. Improved procedures for clearing and staining parasitic and VA mycorrhizal fungi for rapid assessment of infection. Transcriptions of the British Mycological Society 55: 158-160.
Smith SE, Read DJ. 1997. Mycorrhizal symbiosis, 2nd edition. San Diego (CA): Academic Press.

\section{AUTHOR INFORMATION}

Erin L McDermott

Graduate Student

elmcdermott@ucdavis.edu

\section{Alison M Berry}

Professor

amberry@ucdavis.edu

Department of Environmental

Horticulture

University of California

One Shields Avenue

Davis, CA 95616-8587 